\title{
Effect of Calcium and Boron on Growth, Fruit Setting and Yield of Hot Pepper (Capsicum annuum L.)
}

\author{
B.B.M. Salim*, H.G. Abd El-Gawad"*, A. Abou El-Yazied ${ }^{* *}$ and M.S. Hikal $^{* * * *}$ \\ *Department of Agricultural Botany, Faculty of Agriculture, Ain Shams University, Cairo, Egypt \\ ${ }^{* *}$ Department of Horticulture, Faculty of Agriculture, Ain Shams University, Cairo, Egypt \\ ${ }^{* * *}$ Department of Biochemistry, Faculty of Agriculture, Ain Shams University, Cairo, Egypt
}

\begin{abstract}
$\mathbf{T}$ WO successive seasons of 2017 and 2018 were conducted at the Experimental Station of the Faculty of Agriculture, Ain Shams University, Cairo, Egypt to study the response of hot pepper plant (Capsicum annuum L.) cv. Hot Chili growth, fruit setting, yield and some biochemical constituents linked with the yield and quality characteristics to foliar spraying with calcium chloride at 0,1000 and $2000 \mathrm{ppm}$, boric acid at 0,200 and $400 \mathrm{ppm}$ and their combinations. Results indicated that all foliar applications of calcium chloride and boric acid treatments individual or in combination markedly increased the vegetative growth characteristics, fruit setting percentage and fruits yield of hot pepper plants. Foliar spraying with $2000 \mathrm{ppm}$ of calcium chloride plus 200 or $400 \mathrm{ppm}$ of boric acid treatments obviously gave the higher values of plant height, number of branches per plant, shoot fresh and dry weights, fruit setting, fruits yield/ plant and fruits yield/ feddan as well as total carotenoids, vitamin $\mathrm{C}$ and $\mathrm{N}$, $\mathrm{P}$ and $\mathrm{K}$ concentrations compared to the check treatment in both tested seasons.
\end{abstract}

Keywords: Pepper, Capsicum annuum L., Foliar nutrition, Calcium, Boron, Growth, Fruit setting, Yield, Quality

\section{Introduction}

Hot pepper (Capsicum annuum L.) is an important vegetable crop and consumed both as fresh and dehydrated spices and it is considered one of the valuable medicinal plants in the pharmaceutical industries. It is being a good source of antioxidants compounds which is important for human health, i. e. vitamin $C$, provitamin $\mathrm{A}, \mathrm{E}, \mathrm{B}_{1}, \mathrm{~B}_{2}$ and $\mathrm{B}_{3}$, as well as minerals as (potassium, phosphorus and calcium), besides it is an excellent source of natural colors (Bosland and Vostava, 2000, Howard et al., 2000 and Navarro et al., 2006).

In general, there are significant economic losses of horticultural crops had been linked to inadequate calcium nutrition supply, or existing as unavailable form for absorption or immobile element and depends on transpiration rate. Calcium $\left(\mathrm{Ca}^{+2}\right)$ is an essential macronutrient for all higher plants. It is required for various structural roles in the cell wall and membranes and plays a key role in plant growth, fruit development. Also, it is involved in many biochemical and physiological processes in the plants which can improve yield (Marschner, 1995 and White \& Broadley, 2003).

Also, boron (B) has physiological important roles in the strength of cell wall and as part of the cell membranes and also is a vital element in cell division and development as well as it participates in the synthesis of nucleic acid (RNA and DNA), amino acids, proteins, carbohydrates metabolism, starch and sugars transport, indole acetic acid (IAA) metabolism and hormonal regulation, it is a crucial in nitrogen and phosphorus metabolism and pollen tube growth which plays an important role in flowering and fertilization thus boron supply is necessary for improving fruits yield and quality of vegetable crops (Marschner, 1995, Uchida, 2000 and Esringü et al., 2011).

Likewise, several investigations showed that the vegetative growth, yield and quality of vegetable crops positively responded to $\mathrm{Ca}^{+2}$ and B foliar supplies (Davis et al., 2003, El-Tohamy 
et al., 2006, Abd El-Gawad \& Osman 2014 and Buczkowska et al., 2016).

The aim of the current study is to investigate the effect of foliar spraying with calcium chloride, boric acid and their combinations on growth, fruit setting, yield and some biochemical constituents of hot pepper plant.

\section{Materials and Methods}

Two field experiments were carried out during the two growing seasons of 2017 and 2018. Pepper transplants (Capsicum annuum L.) cv. Hot Chili red pepper were transplanted on the last week of March, 2017 and 2018 at the Experimental Farm of the Faculty of Agriculture, Ain Shams University, Shoubra El-Kheima, Egypt. The area of the experimental plot was $12.25 \mathrm{~m}^{2}$ which consisted of five rows, each row was $3.5 \mathrm{~m}$ length and $0.7 \mathrm{~m}$ width. The plant distance was $25 \mathrm{~cm}$ apart on one side in sandy clay loam soil. The experiment was laid out in a split plot design with three replicates. Calcium chloride foliar applications were assigned in the main plots and foliar applications of boric acid were distributed in the sub-plots.

Calcium chloride $\left(\mathrm{CaCl}_{2} \mathrm{Mr} 110\right.$, FlukaGarantia) at 0 (control, sprayed with distilled water), 1000 and 2000 ppm, boric acid $\left(\mathrm{H}_{3} \mathrm{BO}_{3}\right.$ $17 \%$ B) at 0 (control, sprayed with distilled water), 200 and $400 \mathrm{ppm}$ and their combinations treatments compared with tab water (control) were foliar applied at 30, 45 and 60 days after transplanting. The chemical and physical analyses of the experimental soil are shown in Table 1.

\section{Plant material and agricultural practices}

The experimental soil during the preparation for cultivation received $20 \mathrm{~m}^{3} /$ feddan of compost and $150 \mathrm{~kg} /$ feddan of phosphorus as calcium superphosphate $\left(15.5 \% \quad \mathrm{P}_{2} \mathrm{O}_{5}\right)$. After that, 150 $\mathrm{kg} /$ feddan of nitrogen as ammonium sulfate $(20.5 \% \mathrm{~N})$ and $100 \mathrm{~kg} /$ feddan of potassium as potassium sulfate $\left(48 \% \mathrm{~K}_{2} \mathrm{O}\right)$ were added. All the other cultural practices, disease and pest control programs were followed according to the recommendations of the Egyptian Ministry of Agriculture.

Vegetative growth parameters and yield components

At 100 days from transplanting, vegetative growth parameters expressed as plant height, number of branches/ plant, shoot fresh weight, shoot dry weight were determined. Also, number of flowers/plant, number of fruits/plant, fruit set and fruits yield per plant and per feddan were estimated. Fruit set for five plants were labeled randomly before flowering stage from each plot and the fruit set was calculated as follows:

Fruit set $\%=$ (Number of setting fruits $\div$ Total number of flowers) X 100

\section{Biochemical analyses \\ $S P A D$ readings}

SPAD values of the hot pepper leaves were determined using SPAD meter (SPAD-502, Minolta Camera Co., Osaka, Japan) according to Minolta (1989).

\section{Leaf N, $P$ and $K$ concentrations}

Total nitrogen concentration (N) was determined in the dried leaves using microKjeldahl method as described by A.O.A.C. (2000), total phosphorus $(\mathrm{P})$ concentration was estimated calorimetrically using ascorbic acid method described by Watanabe and Olsen (1965) and the concentration of potassium $(\mathrm{K})$ in the digested leaves was determined using flame photometer as described by Eppendrof and Hing (1970).

\section{Total carotenoids concentration}

Total carotenoids in pepper fruits were determined using a spectrophotometric method at a wavelength of $450 \mathrm{~nm}$. Two grams of pepper fruits were extracted in $50 \mathrm{ml}$ of a ternary solvent

TABLE 1. Some chemical and physical analyses of the experimental soil.

\begin{tabular}{|c|c|c|c|c|c|c|c|c|}
\hline \multirow{2}{*}{ pH } & \multirow{2}{*}{$\begin{array}{c}E C \\
(d S / m)\end{array}$} & \multirow{2}{*}{$\begin{array}{c}\mathrm{CaCO}_{3} \\
(\%)\end{array}$} & \multicolumn{3}{|c|}{ Cations (meq /L) } & \multicolumn{3}{|c|}{ Anions (meq/L) } \\
\hline & & & $\mathbf{C a}^{+2}$ & $\mathbf{M g}^{+2}$ & $\mathbf{N a}^{+}$ & $\mathrm{HCO}_{3}^{-}$ & $\mathbf{C L}^{-}$ & $\mathrm{SO}_{4}^{-2}$ \\
\hline 8.47 & 0.79 & 1.48 & 6.50 & 2.50 & 1.52 & 2.59 & 3.24 & 1.70 \\
\hline $\mathrm{N}$ & $\begin{array}{c}\mathrm{P} \\
(\mathrm{ppm})\end{array}$ & $\mathrm{K}$ & \multicolumn{2}{|c|}{ Sand $(\%)$} & Silt (\%) & Clay (\%) & \multicolumn{2}{|c|}{ Soil texture } \\
\hline 89 & 74 & 175 & \multicolumn{2}{|c|}{47.07} & 11.83 & 41.10 & \multicolumn{2}{|c|}{ Sandy clay loam } \\
\hline
\end{tabular}

Egypt. J. Hort. Vol. 46, No. 1 (2019) 
(hexane/ethanol/acetone 50/25/25) for 30 minutes. The solvent after filtration (Whatman, no. 1) was washed three times with $25 \mathrm{ml}$ distilled water and carotenoids concentration was determined using procedures described previously by Ellong et al. (2015).

\section{Ascorbic acid concentration}

Ascorbic acid concentration in pepper fruits was determined according to A.O.A.C. (2000).

\section{Statistical analysis}

All data of the two seasons were arranged and statistically analyzed using Mstat. The comparison among means of the different treatments was determined, as illustrated by Snedecor and Cochran (1982).

\section{Results}

\section{Vegetative growth characteristics}

Data presented in Table 2 indicate that spraying all calcium chloride $\left(\mathrm{CaCl}_{2}\right)$ treatments at 1000 or $2000 \mathrm{ppm}$ gave a stimulate effect on all of the vegetative growth parameters i.e. plant height, number of branches per plant, shoot fresh and dry weights compared to non-sprayed plants in both seasons. Spraying calcium chloride at 2000 ppm gave the highest significant values in plant height, shoot fresh and dry weights compared to check plants in both seasons. On the other hand, all boric acid foliar treatments (200 or 400 ppm) caused significant increases in plant height, shoot fresh and dry weights as compared to the check treatments in both seasons (Table 2), however, the differences were not significant in number of branches per plant in both seasons.

Foliar combination treatments between calcium chloride and boric acid gave significant increases in plant height, number of branches, shoot fresh and dry weights as compared with the check treatment in both seasons. Also, the combination treatments were more effective on all pepper vegetative growth parameters than the individual applications of calcium chloride or boric acid treatments in both seasons. The highest values of these parameters were recorded by the combination between calcium chloride at 2000 ppm with boric acid at 400 ppm followed by the combination between calcium chloride at 2000 ppm with boric acid at $200 \mathrm{ppm}$ in both seasons (Table 2).

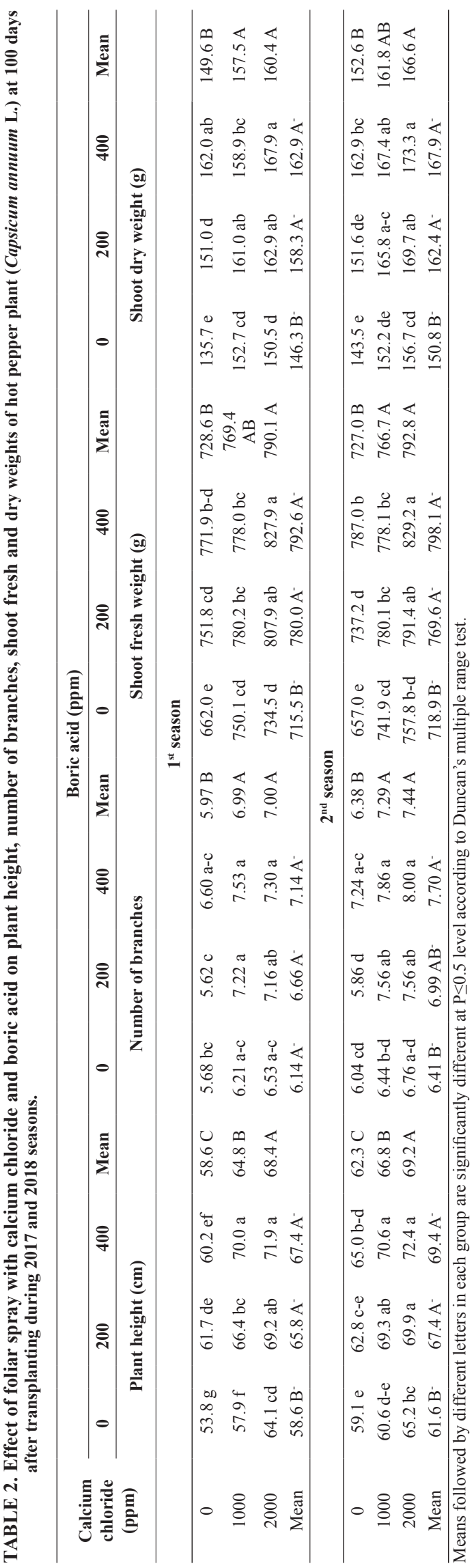

Egypt. J. Hort. Vol. 46, No. 1 (2019) 


\section{Flowering and yield components}

It is clear from Tables 3 and 4 that the yield of hot pepper plant and its components (flowers number, fruit set, number and average weight of fruit, fruits yield/plant and fruits yield/ feddan) increased by all foliar calcium chloride, boric acid and their combinations treatments compared to the check plants. As well, foliar application with $\mathrm{CaCl}_{2}$ treatments produced a significant increase in the number of flowers/ plant in both seasons (Tables 3). A significant increase in number of fruits per plant, fruit weight, fruits yield/plant and total fruits yield/ feddan resulted in plants sprayed with 1000 ppm $\mathrm{CaCl}_{2}$ in both seasons.

Also, using the high level of boric acid (400 ppm) caused a significant increase in the number of flowers/ plant, fruit setting percentage, fruit weight, fruits yield/plant and total fruits yield/ feddan compared to the check plants in both seasons and number of fruits per plant in the second season (Table 3 and 4). The highest concentrations of both $\mathrm{CaCl}_{2}(2000 \mathrm{ppm})$ and boric acid (400 ppm) gave the highest values for tested yield and its components in both seasons. However, no significant differences were detected between the two concentrations of each of $\mathrm{CaCl}_{2}$ and boric acid.

Foliar nutrition with combination between calcium chloride at 1000 or $2000 \mathrm{ppm}$ and boric acid at 200 or 400 ppm gave significant increases in number of flowers per plant, fruit number per plant, fruit setting, fruits yield/plant and fruits yield/ feddan as compared with the check plants in both seasons and fruit weight in the second season (Table 3 and 4). Moreover, spraying hot pepper with the combination between the higher level of $\mathrm{CaCl}_{2}(2000 \mathrm{ppm})$ and each of 200 and 400 ppm boric acid gave the highest values of these parameters in both seasons without significant differences between them (Table 3 and 4).

From presented data (Tables, 2, 3, 4 and 6), spraying hot pepper plants with $400 \mathrm{ppm}$ of boric acid gave 16.45, 11.41, 22.49, 22.51 and $16.35 \%$ increase in shoot dry weight, fruit setting percentage, fruits yield/plant, fruits yield/ feddan and vitamin $\mathrm{C}$ concentration, respectively, while the treated plants with the high level of $\mathrm{CaCl}_{2}$ achieved an increase in shoot dry weight, fruit setting percentage, fruits yield/plant, fruits yield/ feddan and vitamin $\mathrm{C}$ concentration which reached to $10.05,4.79,21.04,21.12$ and $19.95 \%$, respectively, as well the highest increments in the shoot dry weight, fruit setting percentage, fruits Egypt. J. Hort. Vol. 46, No. 1 (2019)

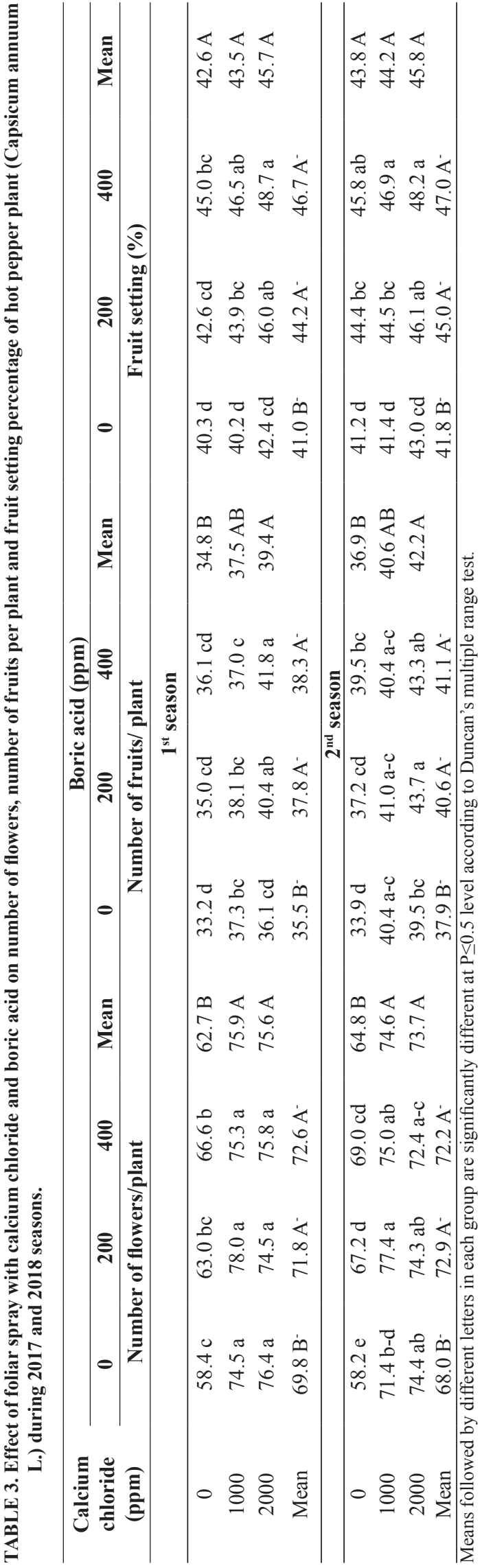




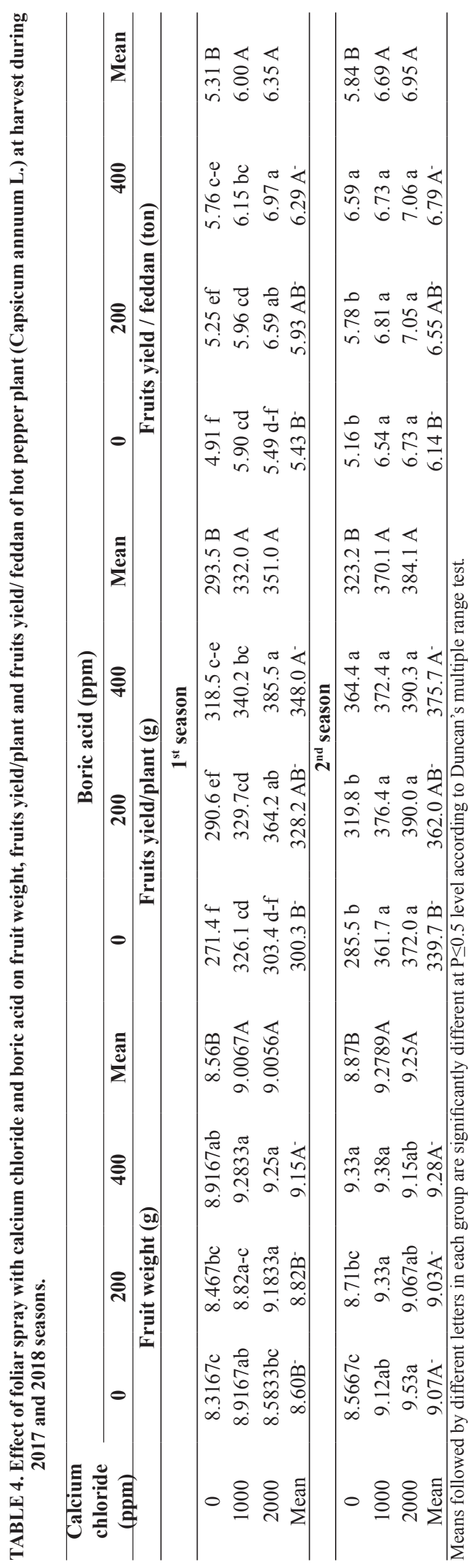

yield/plant, fruits yield/ feddan and vitamin $\mathrm{C}$ concentration were $22.24,18.91,39.37,39.38$ and $31.09 \%$, respectively were recorded by the combination between calcium chloride at 2000 ppm with boric acid at $400 \mathrm{ppm}$.

\section{Biochemical constituents changes}

Data presented in (Tables 5 and 6) indicated that the overall means showed that the leaf concentrations of N, P, K, SPAD readings, fruit content of total carotenoids and vitamin $\mathrm{C}$ of hot pepper plants were responded positively to the individual foliar applications of calcium chloride $\left(\mathrm{CaCl}_{2}\right)$ or boric acid treatments comparing with the check treatment in both seasons. In this concern, the higher levels of each $\mathrm{CaCl}_{2}$ at 2000 ppm and boric acid at $400 \mathrm{ppm}$ recorded the highest values of all tested characters compared with the low level of them and the check plants in both seasons except the concentration of vitamin $\mathrm{C}$ in the first season. However, no significant differences were found between the low and high concentrations of either $\mathrm{CaCl}_{2}$ or boric acid in both seasons.

The combination treatments between calcium chloride at 1000 or $2000 \mathrm{ppm}$ and boric acid at 200 or $400 \mathrm{ppm}$ treatments gave a significant increase in all biochemical constituents, i.e. N, P, SPAD readings, total carotenoids and vitamin $\mathrm{C}$ concentrations compared to the check treatment in both seasons as well as $\mathrm{K}$ concentration in the second season (Tables 5 and 6).

\section{Discussion}

It could be concluded that foliar application with calcium chloride and boric acid individually or in combination stimulated vegetative growth parameters, fruit setting, yield and some biochemical changes of hot pepper plant. The combination of $2000 \mathrm{ppm}$ calcium chloride and 200 or 400 ppm boric acid was the most effective on most of vegetative growth characteristics, yield components and some biochemical constituents which gave the highest values of plant height, number of branches per plant, shoot fresh and dry weights, fruit setting percentage, fruits yield/plant and fruits yield/ feddan as well as total carotenoids, vitamin $\mathrm{C}$, phosphorus and potassium concentrations, in both seasons under the experimental conditions.

These results are in line with those of ElTohamy et al. (2006) who showed improvement of the vegetative growth, i. e. plant height, number

Egypt. J. Hort. Vol. 46, No. 1 (2019) 

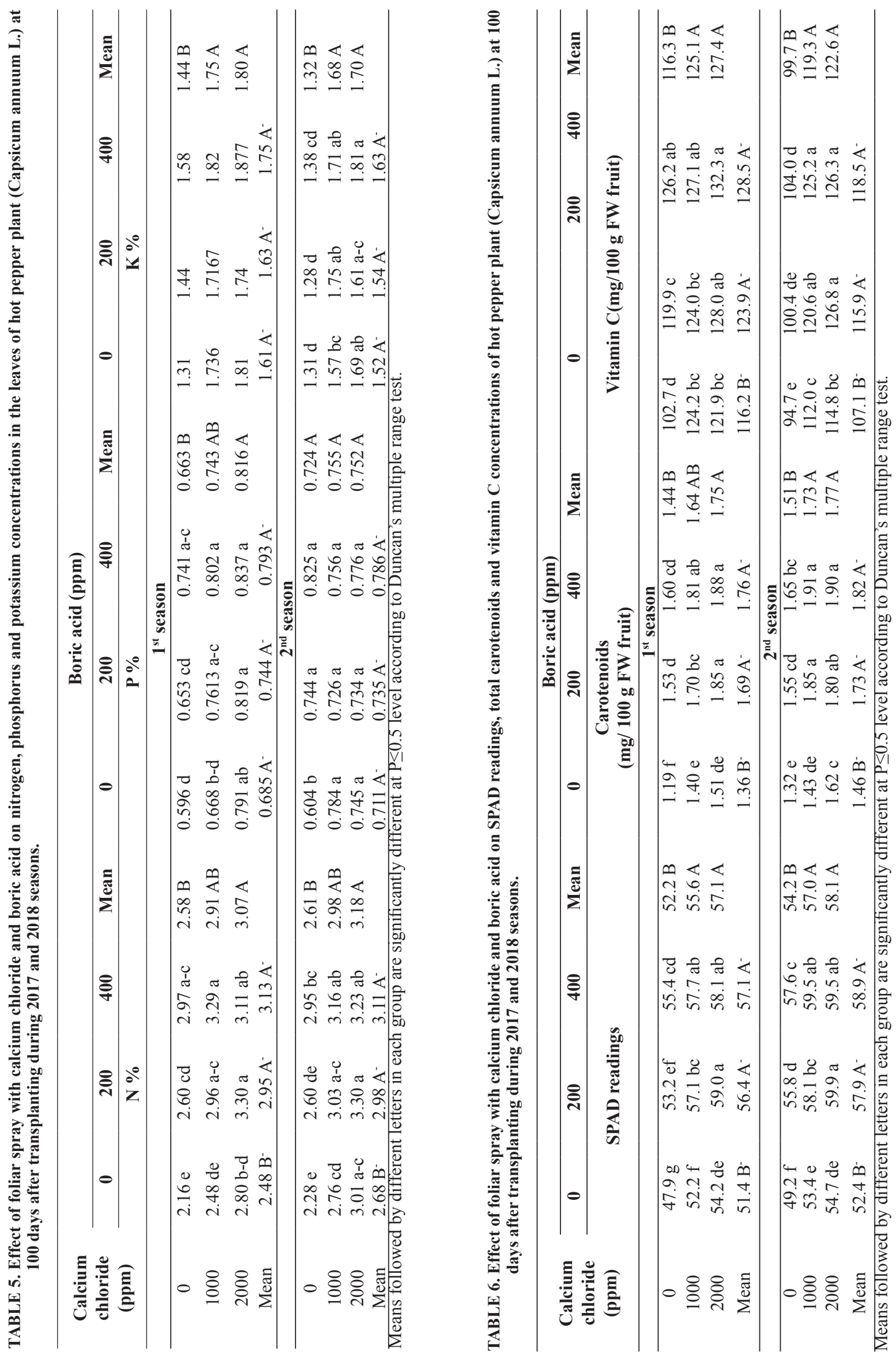

Egypt. J. Hort. Vol. 46, No. 1 (2019) 
of branches, plant fresh weight, fresh weight of fruits, number of fruits and total yield of pepper plants which sprayed with the higher levels of $\mathrm{CaCl}_{2}(2 \%)$ compared to the check plants. Likewise, Kazemi (2014) reported that using calcium chloride at $15 \mathrm{mM}$ as foliar application improved the vegetative, reproductive growth and yield of tomato. Moreover, Buczkowska et al. (2016) found that increment of the total fruits yield of pepper plant under foliar $\mathrm{Ca}^{+2}$ application was $2.8 \%-8.6 \%$, but that of the marketable yield was between $12.1 \%$ and $21.8 \%$ as compared with the total yield $\left(4.99 \mathrm{~kg} \mathrm{~m}^{-2}\right)$ and the marketable yield $\left(3.80 \mathrm{~kg} \mathrm{~m}^{-2}\right)$ which resulted from the check plants. Also, foliar application with $20 \mathrm{mM} \mathrm{CaCl}_{2}$ significantly increased the vegetative growth characteristics of lettuce i. e. plant length, average leaf area, number of leaves/head, head diameter, fresh and dry weights of head (Youssef et al., 2017). As well, Zamban et al. (2018) indicated that foliar spraying with the biweekly application $0.6 \% \mathrm{CaCl}_{2}$ is the best supply for increase fruits fresh weight, total number of fruits, the commercial fruits yield and gave a lower number of fruits with an incidence of blossom end rot of Italian tomato hybrids.

Enhancing some biochemical constituents of hot pepper plant i.e. N, P, K, chlorophyll, total carotenoids, vitamin $\mathrm{C}$ concentrations are in harmony with the findings of El-Tohamy et al. (2006) who reported that using foliar applications with 1 and $2 \%$ of $\mathrm{CaCl}_{2}$ caused a significant increase in the total chlorophyll content of pepper leaves and the high level of $\mathrm{CaCl}_{2}$ was more effective in this concern. Furthermore, Buczkowska et al. (2016) found that, spraying pepper plant with calcium gave a positive effect on chlorophyll content, increased vitamin $\mathrm{C}$ and carotenoids concentrations. As well, foliar application with $20 \mathrm{mM} \mathrm{CaCl}_{2}$ significantly increased photosynthetic pigments (chlorophyll a, b, and total chlorophylls), concentrations of some macro- and micro-nutrients, leaf relative water content (LRWC) and leaf membrane stability index (LMSI) compared with the control plants in both growing seasons (Youssef et al., 2017).

Therefore, improvement the vegetative growth, fruit setting, yield and some physiological changes of hot pepper plant as a result of calcium chloride applications might be due to the physiological roles of calcium $\left(\mathrm{Ca}^{+2}\right)$ which is an essential macronutrient for plant growth and development, is considered as an important intracellular messenger, mediating responses to hormones, a variety of developmental processes, stress signals, essential constituent of the middle lamella in the cell walls structure and for cell membranes formation which affecting normal cells division by maintaining cell integrity and membrane permeability, also it may be an activator for many enzymes in plants, as well as it acts second messenger in metabolic regulation, helping to stabilize in the chromosomes structure and maintaining the ionic balance which benefit to counteract the toxic effects of other nutrients, also it is a counter-cation for inorganic and organic anions in vacuoles and the cytosolic $\mathrm{Ca}^{+2}$ concentration is an obligate intracellular messenger coordinate responses to various developmental cues and environmental stresses (White \& Broadley 2003, Jain 2007 and Hepler \& Winship 2010).

On the other hand, similar results have been further supported by Davis et al., (2003) who indicated that foliar application of boron gave a significant increase in plant height and plant dry weight of tomato as well, using boron $\left(\mathrm{B}_{3} \mathrm{BO}_{3}\right.$ form) as foliar and/ or soil applications improved fruit set, marketable yields, total yields and fruit shelf life of tomato. Moreover, Abou El-Yazied and Mady (2012) showed that B foliar supply stimulated growth characteristics of broad bean as number of leaves per plant, total leaf area, dry weights of both stems and leaves per plant and absolute growth rate as compared with the control plants. Likewise, El-Dissoky and AbdelKadar (2013) revealed that, the vegetative growth parameters, i.e. plant height, number of leaves per plant, leaf area, fresh and dry weights of potato plants were significantly improved by the foliar applications of boron. Also, Salim (2014) found that foliar application with boric acid at 50 and $100 \mathrm{ppm}$ enhanced the vegetative growth of maize (Zea mays L.) irrigated with the saline water as comparing with check plants and the high level of boric acid (100 ppm) was more effective than the low level $(50 \mathrm{ppm})$ in this respect. Also, Harris and Puvanitha (2017) recorded the highest number of fruits per plant by foliar application with $350 \mathrm{ppm}$ of boric acid.

Moreover, Esringu et al. (2011) indicated that, B supply improved concentrations of N, P and K of strawberry tissues that may be due to boron had a synergism effect on increased phosphorus $(\mathrm{P})$, potassium $(\mathrm{K})$, zinc $(\mathrm{Zn})$, manganese $(\mathrm{Mn})$ 
and copper $(\mathrm{Cu})$ content of strawberry tissues. As well, the benefits of boron applications increased the absorption of different nutrients by roots and also improved their translocation and accumulation in plant leaves (Marschner, 1995). Likewise, Abou EL-Yazied and Mady (2012) indicated that foliar application with $50 \mathrm{ppm}$ boron recorded the highest concentrations of $\mathrm{N}$, $\mathrm{P}, \mathrm{K}$ in the leaves of broad bean in both seasons. Also, Abd El-Gawad and Osman (2014) showed that plants received 50 and 100 ppm boric acid as foliar application gave an insignificant increase for the concentration of $\mathrm{N}, \mathrm{P}, \mathrm{K}$ and chlorophyll reading of eggplant leaves as compared with the check treatment. Also, Subba et al. (2016) showed that higher applications of boron had positive effect on ascorbic acid, carotene and total sugars concentrations of carrot roots.

These favorable effects for boric acid foliar applications due to the functional roles of $\mathrm{B}$ is required for normal growth, development, fruits yield and quality of hot pepper plant. Boron enhancing root growth which can increasing water, minerals uptake and translocate in plants, cell wall synthesis, cell division, cell elongation, translocation of sugars and carbohydrates from source to sink, auxin metabolism and the movement of hormones, good pollination and fruit set, synthesis of amino acids and proteins (Marschner, 1995, Sharma, 1995 and Esringü et al., 2011).

Likewise, Hikal et al. (2017) concluded that spraying navel orange trees (Citrus sinensis L. Osbeck) with boric acid at $0.2 \%$ achieved the best results for fruit setting, fruits yield and fruits quality followed by spraying with $2 \% \mathrm{CaCl}_{2}$ treatment.

In addition, Rab and Haq (2012) showed that, the highest values of plant height, number of branches per plant, flowers number per cluster (32.36), fruits number per plant (96.37), fruit weight $(96.33 \mathrm{~g})$ and yield $\left(21.33 \mathrm{tha}^{-1}\right)$ of tomato were recorded by the combination between foliar application of $\mathrm{CaCl}_{2}(0.6 \%)$ plus borax $(0.2 \%)$. Also, Sahin et al., (2015) revealed that, calcium and boron treatments increased both the yield and concentrations of $\mathrm{Ca}$ and $\mathrm{B}$ in tomato leaves.

Also, Zoz et al., (2016) indicated that, Ca and B foliar application stimulates growth, fertilization of flowers, number of fertile tillers and gave higher grains yield of wheat plants. Likewise, Maji et al., (2017) concluded that, the combined

Egypt. J. Hort. Vol. 46, No. 1 (2019) foliar spray of calcium as calcium chloride at $5 \%$ and boron as borax at $0.25 \%$ could be practiced for good vegetative growth, fruits yield and quality of pomegranate (Punica granatum L.) $c v$. BHAGWA.

Moreover, Dong et al. (2009) revealed that, foliar application of the combination between $\mathrm{Ca}$ and $\mathrm{B}$ at rates $\left(1 \mathrm{~g} \mathrm{~kg}^{-1} \mathrm{~B}\right.$ and $\left.2 \mathrm{~g} \mathrm{~kg}^{-1} \mathrm{Ca}\right)$ and $\left(2 \mathrm{~g} \mathrm{~kg}^{-1} \mathrm{~B}\right.$ and $\left.1 \mathrm{~g} \mathrm{~kg}^{-1} \mathrm{Ca}\right)$ is quite useful to improve the quality of navel orange (Citrus sinensis L. Osbeck) for restraining the gene expression and activities of pectinesterase (PE), polygalacturonase $(\mathrm{PG})$ and b-galactosidase (b-Gal) which important function to regulate contents of dietary fiber and improving the tissue structure of segment membrane. As well, sprayed with a $\left(1 \mathrm{~mL} \mathrm{~L}^{-1} \mathrm{Ca}-\mathrm{B}\right)$ solution as $40 \% \mathrm{Ca}$ $\left(\mathrm{NO}_{3}\right)_{2} \cdot 4 \mathrm{H}_{2} \mathrm{O}$ and $0.3 \% \mathrm{H}_{3} \mathrm{BO}_{3}$ at both 60 and 90 days after flowering led to improve the quality of mango fruits i.e. increased the size of the fruit and cells in the exocarp and the mesocarp, gave the highest concentration of vitamin $\mathrm{C}$ and decreased the activities of polygalacturonase and pectin methylesterase (Muengkaew et al., 2018).

Acknowledgments: The authors are grateful to technicians at the experimental farm of the Department of Horticulture, Faculty of Agriculture, Ain Shams University for their help of the study.

Funding statements: Through the authors funding

Conflicts of interest: We declare that they have no conflicts of interest related to the publication of this study.

\section{References}

A.O.A.C. (2000) "Official Methods of Analysis", 17" ed., Association of Official Analytical Chemists, Gaithersburg, MD, Washington, USA.

Abd El-Gawad, H.G. and Osman, H.S. (2014) effect of exogenous application of boric acid and seaweed extract on growth, biochemical content and yield of eggplant. Journal of Horticultural Science \& Ornamental Plants, 6, 133-143.

Abou El-Yazied, A. and Mady, M.A (2012) Effect of boron and yeast extract foliar application on growth, pod setting and both green pod and seed yield of broad bean (Vicia faba L). Journal of American Science, 8, 517- 533.

Bosland, P.W. and Vostava, E.J. (2000) Peppers: vegetable and spice capsicum. CABI publishing, New York, USA. 
Buczkowska, H., Michałojć, Z., and Nurzyńskawierdak, R. (2016) Yield and fruit quality of sweet pepper depending on foliar application of calcium. Turkish Journal of Agriculture and Forestry, 40, 222-228.

Davis T.M., Sanders, D.C. Nelson, P.V., Lengnick, L. and Sperry, W.J. (2003) Boron improves growth, yield, quality and nutrient content of tomato. J Am Soc. Hort. Sci. 128, 441-446.

Dong, T., Xia, R., Xiao, Z., Wang, P. and Song, W. (2009) Effect of pre-harvest application of calcium and boron on dietary fiber, hydrolases and ultrastructure in 'Cara Cara' navel orange (Citrus sinensis L. Osbeck) fruit, Scientia Horticulturae, 121, 272-277.

El-Dissoky, R.A. and Abdel-Kadar, A.E.S. (2013) Effect of boron as a foliar application on some potatoes cultivars under egyptian alluvial soil conditions. Research Journal of Agriculture and Biological Sciences, 9, 232-240.

Ellong, E.N., Billard, C., Adenet, S. and Rochefort, K. (2015) Polyphenols, carotenoids, vitamin C content in tropical fruits and vegetables and impact of processing methods. Food and Nutrition Sciences, 6, 299-313.

El-Tohamy, W.A., Ghoname, A.A. and Abou-Hussein, S.D. (2006) Improvement of pepper growth and productivity in sandy soil by different fertilization treatments under protected cultivation. Journal of Applied Sciences Research, 2, 8-12.

Eppendrof, N. and Hing, G. (1970) Interaction manual of flame photometer B 700-E. Measuring method, Description of the apparatus and Instructions for use.

Esringü, A. , Turan, M., Gunes, A. , Eşitken, A. and Sambo, P. (2011) Boron application improves on yield and chemical composition of strawberry', Acta Agriculturae Scandinavica, Section B - Plant Soil Science, 61, 245 - 252, First published on: 09 March 2011.

Harris, K. D. and Puvanitha, S. (2017) Influence of Foliar Application of Boron and Copper on Growth and Yield of Tomato (Solanum lycopersicum L. cv 'Thilina'). Received: 5th May 2017, Accepted: 18th July 2017, DOI: http://doi.org/10.4038/agrieast. v11i2.35.

Hepler, P.K. and Winship, L.J. (2010) Calcium at the cell wall-cytoplast Interface. J. Integr. Plant Biol., 52, 147-160.
Hikal, A. R. F., Ibrahim, M. A. and Abdelaziz, R. A. (2017) Effect of Different Treatments of Calcium and Boron on Productivity and Fruit Quality of Navel Orange Fruits. Egypt. J. Hort., 44, 119- 126.

Howard, L.R., Talcott, S.T., Brenes, C.H. and Villalon, B. (2000) Changes in phytochemical and antioxidant activity of selected pepper cultivars (Capsicum spp.) as influenced by maturity. Journal of Agricultural and Food Chemistry, 48, 17131720.

Jain, V.K. (2007) Mineral nutrition of plants, fundamentals of plant physiology. S. CHAND\& Company Ltd., Ramnagar, New Delhi- 110055, pp. 100- 110.

Kazemi, M. (2014) Effect of Foliar Application of Humic Acid and Calcium Chloride on tomato growth. Bull. Env. Pharmacol. Life Sci., 3, 41-46.

Maji, S., Yadav, A. and Meena, K.R. (2017) Effect of calcium and boron on growth, yield and quality of pomegranate (Punica granatum L.). Internat. J. Plant Sci., 12, 108-113.

Marschner, H. (1995) Mineral nutrition of higher plants. 2nd Edition, Academic Press, London, 889 PP.

Minolta, (1989) Chlorophyll meter SPAD-502. Instruction manual. Minolta Co., Ltd, Radiometric Instruments Operations, Osaka, Japan.

Muengkaew, R., Whangchai, K. and Chaiprasart, P. (2018) Application of calcium-boron improve fruit quality, cell characteristics, and effective softening enzyme activity after harvest in mango fruit (Mangifera indica L.) Hortic. Environ. Biotechnol., 59, 537- 546.

Navarro, J.M., Flores, P., Garrido, C. and Martinez, V. (2006) Changes in the contents of antioxidant compounds in pepper fruits at different ripening stages, as affected by salinity. Food Chem., 96, 66-73.

Rab, A. and Haq, I. (2012) Foliar application of calcium chloride and borax influences plant growth, yield, and quality of tomato (Lycopersicon esculentum Mill.) fruit. Turk J. Agric. For., 36, 695-701.

Şahin, S., Gebologlu, N. and Karaman, M. R. (2015) Interactive effect of calcium and boron on growth, quality and mineral content of tomato (Solanum lycopersicon L.). Fresenius Environmental Bulletin, 24, 1624- 1628.

Salim, B. B. M. (2014) Effect of Boron and Silicon on Alleviating Salt Stress in Maize. Middle East Journal of Agriculture Research, 3, 1196 -1204.

Egypt. J. Hort. Vol. 46, No. 1 (2019) 
Sharma, S.K. (1995) Response of boron and calcium nutrition on plant growth, fruit growth and seed yield of tomato. Veg. Sci., 22, 27-29.

Snedecor, G.W. and Cochran, W.G. (1982) Statistical Methods, $7^{\text {th }}$ ed., The Iowa State Univ. Press, Ames. Iowa, USA.

Subba, S.K., Chattopadhyay, S. B., Mondal, R. and Dukpa, P. (2016) Effects of potassium and boron on quality parameters of carrot (Daucus carota L.). An International Quarterly Journal of Environmental Sciences, Special issue, Vol. IX, 487-490.

Uchida, R. (2000) Essential Nutrients for Plant Growth: Nutrient Functions and Deficiency Symptoms, Chapter 3, from Plant Nutrient Management in Hawaii's Soils, Approaches for Tropical and Subtropical Agriculture J. A. Silva and R. Uchida, eds. College of Tropical Agriculture and Human Resources, University of Hawaii at Manoa, (C2000, pp. 31- 55 .

Watanabe, F.C. and Olsen, S.R. (1965) Test of ascorbic acid method for determining phosphorus in water and $\mathrm{NaHCO}_{3}$ extracts from soils. Soil Sci. Soc. Am. Proc., 29, 677-678.
White, P.J and Broadley, M.R. (2003). Calcium in Plants. Annals of Botany, 92, 487- 511.

Youssef, S.M.S., Abd El-Hady, S.A., Nashwa A.I. Abu El-Azm, El-Shinawy, M.Z. (2017) Foliar Application of Salicylic Acid and Calcium Chloride Enhances Growth and Productivity of Lettuce (Lactuca sativa). Egypt. J. Hort., 44, 1-16.

Zamban, D.T, Prochnow, D., Caron, B. O., Turchetto, M., Fontanam, D. C. and Schmidt, D. (2018) Applications of calcium and boron increase yields of Italian tomato hybrids (Solanum lycopersicum) in two growing seasons. Rev. Colomb. Cienc. Hortic., 12, 82- 93.

Zoz, T., Steiner, F., Seidel, E. P., Castagnara, D. D. and de Souza, G. E. (2016) Foliar application of calcium and boron improves the spike fertily and yield of wheat. Biosci. J., Uberlândia, 32, 873-880.

(Received 19/11/2018; (accepted 21/01/2019

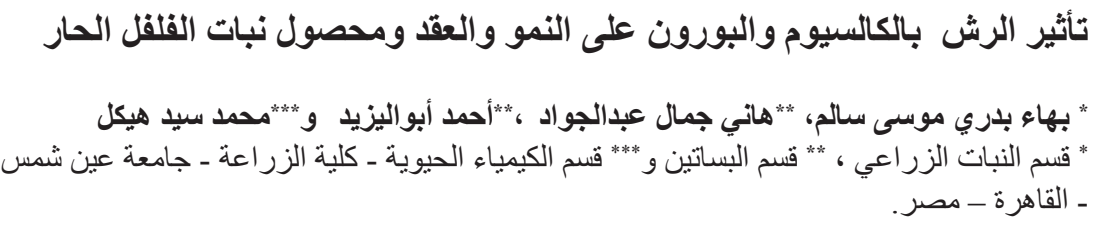

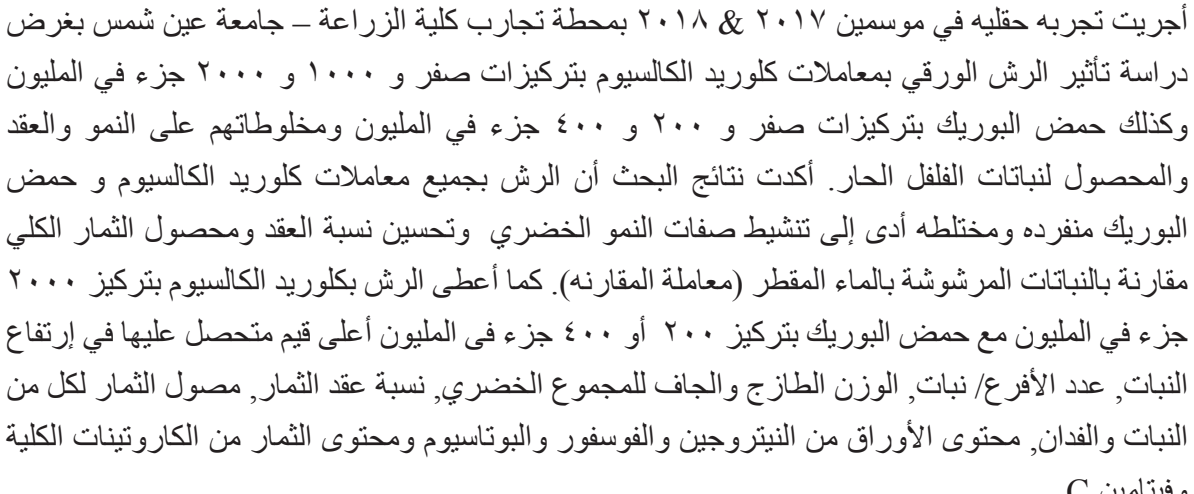

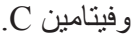

